\title{
PERANCANGAN KAMPANYE SOSIAL PENCEGAHAN KANKER SERVIKS TERHADAP REMAJA WANITA DI KOTA JAKARTA
}

\author{
Denisha Octavia ${ }^{1}$, Atria Nuraini Fadilla ${ }^{2}$ \\ 1,2 Universitas Telkom
}

\begin{abstract}
Abstrak: Indonesia merupakan negara penderita kanker serviks terbanyak dengan penderita sebanyak kurang lebih 330.000 orang wanita. Perkembangan zaman saat ini banyak mengubah perilaku para remaja wanita khususnya di kota Jakarta yang dapat mempengaruhi terjadinya kanker serviks seperti merokok, berhubungan seks di usia muda, memiliki banyak pasangan seksual, penderita HIV/AIDS dan pengunaan vaginal douching. Tujuan perancangan ini adalah untuk memberikan awareness kepada remaja wanita dalam mencegah kanker serviks sejak usia dini melalui suntik vaksin HPV (Human Papilloma Virus). Metode pengumpulan data yang digunakan adalah metode observasi kepada Kementerian Kesehatan RI, wawancara para ahli kanker dan kampanye, hasil kuesioner dan studi pustaka. Hasil dari analisis data observasi, wawancara dan kuesioner yang telah dilakukan yaitu diperlukan sebuah kampanye sosial kepada remaja wanita di kota Jakarta melalui pendekatan media terhadap remaja dengan perancangan program suntik vaksin HPV roadshow dan beberapa media. Media yang digunakan berupa animasi, poster, $x$-banner, brosur, booth, photobooth, ambient advertising, baju, dan merchandise (kipas tangan, stiker, tas pembalut, tumbler, goodie bag). Pendekatan media dilakukan untuk memberikan awareness kepada remaja wanita dalam melakukan kampanye sosial pencegahan kanker serviks di kota Jakarta.
\end{abstract}

Kata kunci : kampanye sosial, kanker serviks, remaja wanita, vaksin HPV, Jakarta

\begin{abstract}
Indonesia is the country with the largest cervical cancer patients with approximately 330,000 women. The development of the current era has changed the behavior of teenage girls especially in the city of Jakarta that can affect the occurrence of cervical cancer such as smoking, having sex at a young age, having multiple sexual partners, HIV / AIDS patients and the use a vaginal douching. The purpose of this design is to provide awareness to adolescent women in preventing cervical cancer from an early age through injecting HPV vaccine (Human Papilloma Virus). Data collection methods used were observational methods to the Ministry of Health, cancer and campaigns interviews, questionnaires and literature study. The results of observational data analysis, interviews and questionnaires that have been done that is required a social campaign to young women in the city of Jakarta through a media approach to adolescents with the design of $H P V$ vaccine injection program roadshow and some media. Media used in the form of animation, poster, $x$-banner, brochure, booth, photobooth, ambient advertising, clothes, and merchandise (hand fan, sticker, bag pads, tumbler, goodie bag). A media approach is
\end{abstract}

Penulis adalah mahasiswa dan staf pengajar jurusan Desain Komunikasi Visual, Fakultas Industri Kreatif Universitas Telkom, email: denishaoctavia@gmail.com, atria.fadilla@gmail.com 
conducted to provide awareness to adolescent girls in conducting social campaigns for cervical cancer prevention in the city of Jakarta.

Keywords: social campaigns, cervical cancer, adolescent women, HPV vaccine, Jakarta

\section{PENDAHULUAN}

Kanker merupakan penyakit yang dapat mematikan manusia. Berdasarkan data Riset Kesehatan Dasar (Riskesdas) 2013, kasus kanker di Indonesia terjadi sebanyak lebih kurang 330.000 orang dengan kasus terbesar adalah kanker serviks. Banyaknya penderita kanker serviks di Indonesia terjadi di kota-kota berkembang salah satunya Kota Jakarta. Jumlah penderita kanker di Indonesia yang sudah tinggi ini diperkirakan oleh World Health Organization (WHO) akan meningkat hingga 7 kali lipat pada tahun 2030 mendatang (Yayasan Peduli Kanker Serviks Indonesia 2012).

Kanker Serviks disebabkan oleh virus papiloma manusia (human papilloma virus) atau disebut juga HPV yang dapat menyerang leher rahim. Perjalanan infeksi virus menjadi sebuah kanker membutuhkan waktu sekitar 10-20 tahun. Hal ini menjadikan pola dan gaya hidup sejak remaja sangat mempengaruhi terjadinya kanker serviks dikemudian hari.

Perkembangan zaman saat ini banyak mengubah perilaku para remaja wanita khususnya di Jakarta seperti Melakukan hubungan seks di usia muda, bergontaganti pasangan seksual, terkena penyakit menular seksual, merokok dan terkena HIV/AIDS. Hal tersebut merupakan faktor penunjang terjadinya kanker serviks.

Kanker serviks dapat dicegah melalui suntik vaksin HPV yang dapat dilakukan sejak umur 9 tahun. Hanya saja masih banyak remaja wanita yang belum mengetahui suntik vaksin HPV. Kementerian Kesehatan Republik Indonesia sudah melalukan beberapa upaya mengenai pencegahan kanker serviks, namun media yang digunakan masih tergolong minim sehingga masih banyak masyarakat terutama remaja wanita tidak mengetahui upaya tersebut, dan upaya yang 
dilakukan belum memiliki sebuah kampanye atau informasi yang ditujukan khusus kepada remaja wanita.

Dari permasalahan tersebut penulis tertarik untuk mengkajinya dalam perancangan tugas akhir ini melalui perancangan kampanye sosial pencegahan kanker serviks terhadap remaja wanita di kota Jakarta dengan tujuan untuk memberikan awareness mengenai bahayanya penyakit kanker serviks dan ajakan melakukan suntik vaksin HPV serta menjaga kebersihan area kewanitaan untuk mencegah kanker serviks sejak dini.

\section{KAJIAN TEORI}

Dalam buku Venus (2004 : 07), Rogers dan Storey (1987) mendefinisikan kampanye sebagai serangkaian tindakan komunikasi yang terencana dengan tujuan menciptakan efek tertentu pada sejumlah besar khalayak yang dilakukan secara berkelanjutan pada kurun waktu tertentu. Dalam definisi tersebut mengandung empat hal yakni (1) tindakan kampanye yang ditujukan untuk menciptakan efek atau dampak tertentu, (2) jumlah khalayak sasaran yang besar, (3) biasanya dipusatkan dalam kurun waktu tertentu, dan (4) melalui serangkaian tindakan komunikasi yang terorganisasi. Perancangan ini menggunakan jenis kampanye Ideologically or Cause Oriented Campaigns yang beriorientasi pada tujuan yang bersifat khusus dan berdimensi perubahan sosial.

Kolter menyebut kampanye ini sebagai social change campaigns yaitu kampanye yang tujuannya untuk menangani masalah-masalah sosial melalui perubahan perilaku dan sikap publik yang terkait.

Menurut Karfried Knapp, komunikasi merupakan interaksi antarpribadi yang menggunakan sistem simbol linguistik, seperti sistem simbol verbal (kata-kata) dan nonverbal. Sistem ini dapat disosialisasikan secara langsung/tatap muka atau melalui media lain (tulisan, oral, dan visual). Hovland, Janis, dan Kalley memberikan penekanan bahwa kegiatan komunikasi mempunyai tujuan 
mengubah atau membentuk perilaku orang lain yang menjadi sasaran komunikasi (Suryanto, 2015 : 52-54). Bentuk komunikasi yang digunakan dalam perancangan ini yaitu komunikasi massa yang merupakan human communication atau suatu tipe komunikasi manusia yang lahir bersamaan dengan menggunakan alat-alat mekanik yang mampu melipatgandakan pesan-pesan komunikasi (Wiryanto, 2000).

Dalam buku Tinarbuko (2015:05) mengatakan bahwa Desain komunikasi visual adalah ilmu yang mempelajari konsep komunikasi dan ungkapan daya kreatif yang diaplikasikan dalam berbagai media komunikasi visual dengan mengolah elemen desain grafis seperti gambar (ilustrasi), huruf, warna, komposisi, dan layout. Semuanya itu berguna untuk menyampaikan pesan secara audio, visual, dan audio visual kepada khalayak sasaran yang dituju. Menurut Ibiz Fernandez Animasi adalah sebuah proses merekam dan memainkan kembali serangkaian gambar statis untuk mendapatkan sebuah ilusi pergerakan yang memberi kesan menghidupkan atau usaha untuk menggerakan sesuatu yang tidak dapat bergerak sendiri (Palupi, $2016: 28$ ).

\section{METODE PENELITIAN}

Dalam pengumpulan data yang dilakukan metode yang digunakan dalam perancangan ini yaitu metode observasi, wawancara, kuesioner dan studi literatur. Metode observasi yaitu pengumpulan data aspek Imaji atau karya visual yang merupakan berbagai karya desain komunikasi visual yang kemudian di teliti dan memberikan sensasi kepada otak untuk dikemas menjadi presepsi kemudian disatukan menjadi informasi dan komponen-komponen yang dapat di kategorikan dan diinterpresentasikan (Soewardikoen, 2013: 19)

Menurut Koentjaraningrat (1980) dalam buku Soewardikoen (2013: 20), wawancara merupakan penggalian konsep, pemikiran, dan pengalaman pribadi atau pandangan dari individu atau narasumber. Sebagai saluran untuk 
mentransfer pengetahuan narasumber seperti Kementerian Kesehatan RI dan para ahli kedokteran dan kampanye yang dilakukan secara tatap muka.

Kuesioner adalah metode pengumpulan data untuk mendapatkan data dari khalayak banyak atau sulit dilakukan dengan wawancara yang berguna untuk mengetahui informasi dan mempelajari sikap, keyakian, perilaku dan karateristik khalayak sasaran (Soewardikoen, 2013:25).

Studi kepustakaan menurut Nazir (1988) adalah teknik pengumpulan data dengan mengadakan studi penelaah terhadap buku, literatur, catatan, dan laporan yang ada hubungannya dengan masalah yang dipecahkan (Winarto, 2015 :05).

Metode analisis yang digunakan yaitu metode analisis matriks dan AISAS. Metode matriks dilakukan sebagai analisis pembanding dengan kampanye sejenis lainnya. Pada prinsipnya, analisis matriks adalah juxtaposition atau membandingkan objek visual dengan dijajarkan dan dinilai menggunakan satu tolak ukur yang sama untuk melihat perbedaannya, misalnya membandingkan poster akan terlihat perbedaan gaya gambar dan gangrenya (Soewardikoen, 2013:50). Sedangkan metode AISAS digunakan sebagai analisis penggunaan media terhadap informasi yang diberikan. AISAS adalah model komprehensif yang mengantisipasi perilaku beragam konsumen modern. Hal ini menunjukkan bahwa pemasar harus strategis merancang mekanisme yang akan memandu konsumen untuk mengunjungi situs resmi, kemudian memotivasi mereka untuk mencari, kemudian konsumen akan dengan senang hati berbagi pengalaman mereka di blog atau media sosial, dan meningkatkan intensitas komunikasi Word of Mouth (Hendriyani 2013 dalam prasetyo, 2016: 39).

\section{DATA DAN ANALISIS}

Kota Jakarta menduduki posisi peringkat nomer empat dengan jumlah penderita kanker serviks terbanyak setelah kota Bali, Jawa Tengah dan Jawa Timur. Jumlah penduduk wanita dengan usia 30-50 tahun di Kota Jakarta sebanyak 
1.665.148 orang dengan kasus terbesar 4.799 orang terdeteksi kanker serviks dari data Kementerian Kesehatan RI tahun 2014-2016 (Kementerian Kesehatan, 2017).

\begin{tabular}{|c|c|c|c|}
\hline \multicolumn{3}{|c|}{$\begin{array}{l}\text { DATA TOTAL IVA DAN CURIGA KANKER SERVIKS TAHUN } 2007 \text { - } 2016 \\
\text { KEMENTERIAN KESEHATAN REPUBLIK INDONESIA }\end{array}$} & \multirow{2}{*}{$\begin{array}{l}\text { GA KANKER } \\
\text { ERVIKS }\end{array}$} \\
\hline PROVINSI & $\begin{array}{l}\text { JUMLAH PENDUDUK } \\
30-50 \text { thn }\end{array}$ & TOTAL IVA POSITIF & \\
\hline Sumatera Utara & 1.853 .941 & 754 & 26 \\
\hline Sumatera Barat & 685.565 & 753 & 3 \\
\hline Riau & 899.417 & 821 & 56 \\
\hline Jambi & 499.520 & 522 & 7 \\
\hline Lampung & 1.165 .939 & 1.337 & 227 \\
\hline Bangka Belitung & 195.565 & 129 & 9 \\
\hline DKI Jakarta & 1.665 .148 & 4.799 & 269 \\
\hline Jawa Barat & 6.838 .318 & 2.310 & 173 \\
\hline Jawa Tengah & 4.964 .317 & 20.548 & 111 \\
\hline DIY & 539.404 & 2.834 & 52 \\
\hline Jawa Timur & 6.012 .729 & 17.824 & 187 \\
\hline Banten & 1.822 .567 & 93 & 1 \\
\hline Bali & 645.583 & 12.653 & 254 \\
\hline NTB & 722.347 & 1.015 & 53 \\
\hline NTT & 638.355 & 312 & 9 \\
\hline Kalimantan Barat & 665.354 & 948 & 124 \\
\hline Kalimantan Tengah & 367.946 & 263 & 6 \\
\hline Kalimantan Timur & 509.706 & 102 & 2 \\
\hline Kalimantan Utara & 87.409 & 87 & 24 \\
\hline Sulawesi Selatan & 1.219 .200 & 834 & 112 \\
\hline Sulawesi Tenggara & 331.931 & 482 & 11 \\
\hline Sulawesi Barat & 180.443 & 88 & 3 \\
\hline Papua Barat & 119.863 & 85 & 20 \\
\hline
\end{tabular}

Gambar 1 Data Total IVA Positif dan Curiga Kanker Serviks Tahun 2004-2016

Sumber: Kementerian Kesehatan RI

Hasil wawancara oleh Kementerian kesehatan RI yang telah dilakukan dapat disimpulkan bahwa saat ini Kementerian Kesehatan RI belum memiliki sebuah kampanye tersendiri dalam melakukan himbauan pencegahan kanker serviks terhadap remaja wanita khususnya diusia 14-21 tahun. Kementerian Kesehatan RI telah memberikan beberapa media himbauan seperti poster dan brosur mengenai pencegahan kanker serviks hanya saja masih banyak remaja yang belum mengetahui adanya media tersebut. Minimnya media yang digunakan menjadikan kurang efektifnya komunikasi yang dilakukan kepada khalayak sasaran. 
Sedangkan hasil wawancara yang dilakukan kepada dokter ahli kandungan resiko tinggi Dr. dr. Yuditiya Purwosunu., Sp.OG-KFM, Ph.D mengatakan bahwa penunjang terjadinya kanker serviks dimulai dari pola dan gaya hidup sejak remaja maka dari itu untuk mencegahan kanker serviks sejak remaja yaitu dengan menjaga pola dan gaya hidup sehat. Selain itu melakukan suntik vaksin HPV agar pencegahan semakin efektif. Untuk hasil wawancara kepada bapak Dr. Antar Venus, M.A, Comm sebagai ahli bidang kampanye mengatakan bahwa dalam melakukan kampanye sosial tersebut dibutuhkannya sebuah media yang tepat sesuai dengan remaja dan juga sebuah gerakan partisipasi remaja agar kampanye sosial pencegahan kanker serviks ini dapat dukungan langsung dari khalayak sasaran.

Hasil dari kuesioner yang disebarkan kepada 246 responden dapat disimpulkan bahwa penggunaan visual yang menarik seperti ilustrasi berjenis vektor, penggunaan huruf sans serif yang memiliki ciri tidak tegak lurus dan memiliki kesan bersahabat dapat menarik perhatian mereka. Selain itu visual yang digunakan juga harus sememperhatikan prinsip desain yaitu keseimbangan, kesatuan, proporsi, irama, dan penekanan / fokus. Dengan memperhatikan hal tersebut akan membuat visual pada kampanye seimbang dan memiliki ciri khas.

\section{HASIL DAN DISKUSI}

Kanker serviks merupakan penyakit yang dapat mematikan para wanita. Pola dan gaya hidup sejak remaja sangat mempengaruhi terjadinya kanker serviks dikemudian harinya. Hampir disetiap tahun data penderita yang terdeteksi kanker serviks di kota Jakarta meningkat. Kementerian Kesehatan RI belum memiliki sebuah kampanye tersendiri dalam melakukan himbauan pencegahan kanker serviks terhadap remaja wanita khususnya usia 14-21 tahun. Sedangkan menghimbauan remaja mengenai pencegahan kanker serviks sejak dini sangat di perlukan, karena pola dan gaya hidup sejak remaja menentukan terjadinya kanker 
serviks di kemudian harinya. Kementerian Kesehatan RI telah memberikan beberapa media himbauan seperti poster dan brosur mengenai pencegahan kanker serviks. Minimnya media yang digunakan membuat remaja masih belum mengetahui adanya informasi tersebut. Sebagian dari remaja yang pernah melihat informasi tersebut mengatakan informasi tersebut belum menarik dan jelas sehingga informasi tersebut belum tersampaikan dengan baik. Selain itu dilihat dari beberapa perbandingan kampanye sejenis lainnya, media yang dilakukan kementerian kesehatan RI masih tergolong umum dan belum memiliki sebuah penghimbauan yang secara khusus terhadap target. Hal ini menjadikan kurang efektifnya komunikasi yang dilakukan kepada khalayak sasaran.

Untuk itu dibutuhkan sebuah kampanye sosial mengenai pencegahan kanker serviks terhadap remaja di usia 14-21 tahun, untuk menghimbau dan memberikan informasi kepada remaja mengenai pentingnya menjaga pola dan gaya hidup di usia remaja dalam mencegah terjadinya kanker serviks. Dalam melakukan kampanye sosial tersebut dibutuhkannya sebuah media yang tepat sesuai dengan remaja. Selain menggunakan media yang tepat, dibutukan juga sebuah gerakan partisipasi remaja dalam melakukan kampanye sosial pencegahan kanker serviks ini. Agar kampanye sosial pencegahan kanker serviks ini dapat dukungan langsung dari khalayak sasaran. Penggunaan visual yang akan digunakan dalam kampanye pencegahan kanker serviks ini juga harus sesuai dengan memperhatikan prinsip desain yaitu keseimbangan, kesatuan, proporsi, irama, dan penekanan / fokus. Dengan memperhatikan hal tersebut akan membuat visual pada kampanye seimbang dan memiliki ciri khas. Dibutuhkannya sebuah visual untuk menarik perhatian mereka dalam informasi yang disampaikan. Hasil kuesioner mengatakan bahwa visual yang remaja sukai adalah visual berbentuk ilustrasi vektor. Ilustrasi ini akan dijadikan acuan dalam perancangan kampanye sosial pencegahan kanker serviks ini. Dengan melakukan perancangan sesuai pendekatan terhadap remaja, diharapkan informasi yang diberikan dapat 
tersampaikan dengan baik. Sehingga remaja tertarik dan teredukasi dari pesan yang disampaikan.

\section{KONSEP PERANCANGAN}

Dalam melakukan kampanye sosial tersebut dibutuhkannya beberapa konsep diantaranya :

Konsep Pesan. Pesan utama dalam kampanye ini yaitu "Peduli Serviks" dengan mengajak melakukan imunisasi HPV. Gaya pesan yang akan digunakan yaitu rasional dan emosional. Gaya pesan rasional ini digunakan pada slogan kampanye yaitu "Ayo lakukan suntik vaksin HPV 3x untuk selamanya" selain itu digunakan juga sebagai penyampaian isi informasi yang akan disampaikan pada media. Sedangkan untuk gaya pesan emosional digunakan pada bodycopy "Tak akan ada hari esok jika kanker menyerang, cegah dari sekarang".

Konsep Kreatif. Konsep kreatif yang dilakukan menggunakan pendekatan "viral dan diskon" dengan mengajak khalayak sasaran foto selfie ntuk mendapatkan potongan harga untuk melakukan suntik vaksin HPV. Selain itu adanya pemilihan duta kanker serviks sebagai ambassador yang dapat dijadikan contoh oleh remaja masa kini.

Konsep Visual. Dalam perancangan ini konsep visual dibagi menjadi dua antara lain identitas visual dan media kampanye. Gaya visual yang digunakan yaitu menggunakan gaya visual flat design. Dengan menggabungkan tema kesehatan dengan menggunakan warna-warna feminim. Unsur-unsur desain yang digunakan seperti: (1) Elemen Visual yang digunakan yaitu bentuk tanda tambah dan suntikan yang merupakan unsur dari kesehatan. Selain elemen visual lainnya yaitu karakter seorang remaja sebagai icon dalam setiap media. Perancangan ini juga menggunakan logo kampanye dan logo kementerian kesehatan RI. (2) Warna yang digunakan yaitu warna teal, putih dan pink. Teal dan putih merupakan warna dari pita peduli kanker serviks, sedangkan warna pink sebagai warna dari ciri khas 
seorang wanita yang mencirikan feminim. (3) Tipografi jenis sans serif merupakan jenis tipografi yang digunakan dalam perancangan ini untuk memberikan kesan bersahabat dan hangat. Perancangan ini menggunakan 3 paduan huruf diantaranya huruf Century Gothic, Riffic Free Medium dan Franklin Gothic Heavy. (4) Layout pada perancangan ini akan menyesuaikan dengan setiap media yang digunakan untuk mempermudah keterbacaan informasi yang disampaikan. (5) Sedangkan untuk ilustrasi yang digunakan pada perancangan ini yaitu jenis vektor dengan gaya visual flat.

Identitas Visual. Konsep identitas visual pada perancangan ini yaitu menggunakan gambar suntikan yang menggambarkan tujuan dari kampanye ini. Sebagian dari gambar suntikan tersebut digabungkan dengan typografi yang dibentuk menyesuaikan gambar suntikan. Suntikan berartikan sebagai lambang dari program kampanye AKSI Peduli Serviks yaitu program suntik vaksin HPV roadshow. Sedangkan tipografi yang digunakan menggunakan dua jenis font yaitu Boulodrome dan Lakesight Personal Use Only. Warna yang digunakan pada logo kampanye AKSI Peduli Serviks ini menggunakan warna teal dan pink. Teal merupakan warna dari bagian pita peduli kanker serviks. Sedangkan untuk warna pink digunakan sebagai ciri khas seorang wanita dan memberikan kesan feminim.

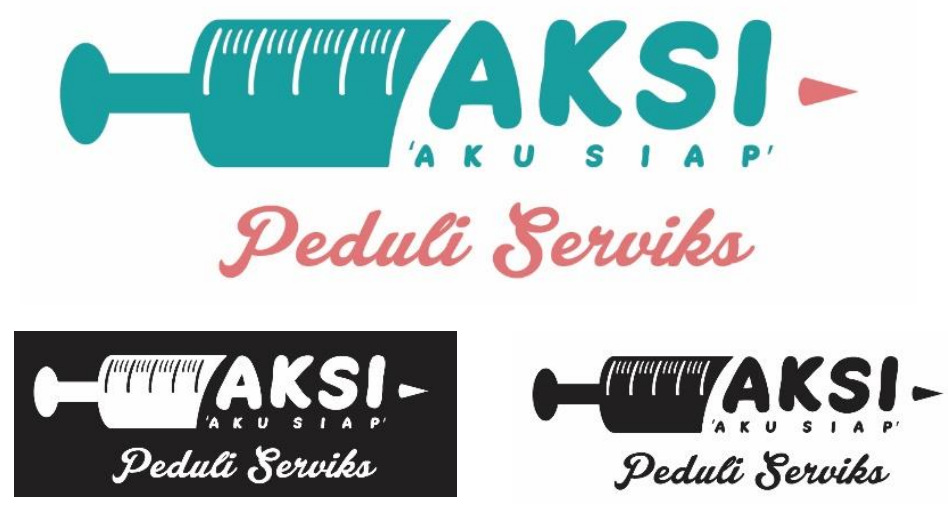

Gambar 2. Logo Kampanye AKSI Peduli Serviks Sumber: Denisha, $2017: 148$ 
Konsep Media. Strategi media komunikasi visual yang digunakan yaitu media utama, media pendukung dan media merchandise. Media-media tersebut akan disesuaikan dengan teori AISAS agar pesan yang diberikan dapat tersampaikan dengan baik dan diterima oleh khalayak sasaran.

Tabel 1. Tahapan media model AISAS

\begin{tabular}{|c|c|c|c|}
\hline Tahapan & Media & Lokasi & Tujuan \\
\hline \multirow{5}{*}{ Attention } & Animasi & $\begin{array}{l}\text { Youtube, facebook } \\
\text { dan instagram }\end{array}$ & \multirow{5}{*}{$\begin{array}{l}\text { Untuk menarik } \\
\text { perhatian khalayak } \\
\text { sasaran terhadap } \\
\text { informasi yang } \\
\text { diberikan }\end{array}$} \\
\hline & Poster Digital & $\begin{array}{l}\text { facebook dan } \\
\text { instagram }\end{array}$ & \\
\hline & Poster Cetak & Sekolah dan Kampus & \\
\hline & Brosur & $\begin{array}{l}\text { Sekolah dan program } \\
\text { suntik vaksin } \\
\text { roadshow (car free } \\
\text { day) }\end{array}$ & \\
\hline & $X$-banner & $\begin{array}{l}\text { Sekolah dan program } \\
\text { suntik vaksin } \\
\text { roadshow (car free } \\
\text { day) }\end{array}$ & \\
\hline \multirow{4}{*}{ Interest } & Tamplate Foto Selfie & $\begin{array}{l}\text { Instagram dan } \\
\text { Facebook }\end{array}$ & \multirow{4}{*}{$\begin{array}{l}\text { Untuk menarik } \\
\text { perhatian khalayak } \\
\text { sasaran dan } \\
\text { mengajak untuk } \\
\text { berpartisipasi dalam } \\
\text { gerakan pencegahan } \\
\text { kanker serviks. }\end{array}$} \\
\hline & Marchandise & $\begin{array}{l}\text { Program suntik } \\
\text { vaksin roadshow (car } \\
\text { free day) }\end{array}$ & \\
\hline & $\begin{array}{l}\text { Poster Digital ajakan } \\
\text { foto selfie }\end{array}$ & $\begin{array}{l}\text { Instagram dan } \\
\text { Facebook }\end{array}$ & \\
\hline & $\begin{array}{l}\text { Poster Cetak ajakan } \\
\text { aksi foto selfie }\end{array}$ & Sekolah dan kampus & \\
\hline Search & Media Sosial & $\begin{array}{l}\text { Instagram dan } \\
\text { Facebook }\end{array}$ & $\begin{array}{l}\text { Untuk meningkatkan } \\
\text { rasa ingin tau } \\
\text { khalayak sasaran dan } \\
\text { mempermudah } \\
\text { khalayak sasaran } \\
\text { mecari informasi } \\
\text { yang dibutuhkan } \\
\text { melalui pendekan } \\
\text { media yang mereka } \\
\text { gunakan }\end{array}$ \\
\hline
\end{tabular}




\begin{tabular}{|c|c|c|c|}
\hline \multirow{7}{*}{ Action } & Booth & $\begin{array}{l}\text { Program suntik } \\
\text { vaksin roadshow (car } \\
\text { free day) }\end{array}$ & \multirow{7}{*}{$\begin{array}{l}\text { Adanya gerakan } \\
\text { khalayak sasaran } \\
\text { terhadap kampanye } \\
\text { yang disampaikan }\end{array}$} \\
\hline & Photobooth & $\begin{array}{l}\text { Program suntik } \\
\text { vaksin roadshow (car } \\
\text { free day) }\end{array}$ & \\
\hline & X Banner & $\begin{array}{l}\text { Program suntik } \\
\text { vaksin roadshow (car } \\
\text { free day) }\end{array}$ & \\
\hline & Brosur & $\begin{array}{l}\text { Program suntik } \\
\text { vaksin roadshow (car } \\
\text { free day) }\end{array}$ & \\
\hline & Ambient Media & $\begin{array}{l}\text { Program suntik } \\
\text { vaksin roadshow (car } \\
\text { free day) }\end{array}$ & \\
\hline & T-Shirt & $\begin{array}{l}\text { Program suntik } \\
\text { vaksin roadshow (car } \\
\text { free day) }\end{array}$ & \\
\hline & Merchandise & $\begin{array}{l}\text { Program suntik } \\
\text { vaksin roadshow (car } \\
\text { free day) }\end{array}$ & \\
\hline Share & Media Sosial & $\begin{array}{l}\text { Instagram dan } \\
\text { Facebook }\end{array}$ & $\begin{array}{l}\text { Khalayak sasaran } \\
\text { mengajak orang } \\
\text { terdekat maupun } \\
\text { orang lain untuk ikut } \\
\text { partisipasi dalam } \\
\text { pencegahan kanker } \\
\text { serviks setelah } \\
\text { merasakan dampak } \\
\text { positif yang telah } \\
\text { didapatkan. }\end{array}$ \\
\hline
\end{tabular}

Sumber: Denisha Octavia, 2017.

Perancangan media. Media yang digunakan pada kampanye ini terdiri dari media utama antara lain (1) animasi, animasi merupakan media informasi yang bertujuan untuk memberikan pemahaman melalui video ilustrasi berupa animasi dalam melakukan pendekatan terhadap khalayak sasaran. (2) Poster digital digunakan untuk memberikan informasi melalui media sosial facebook dan 
instagram. (3) Poster cetak, bertujuan untuk memberikan informasi secara langsung kepada khalayak sasaran yang dibuat semenarik mungkin menyesuaikan karakteristik khalayak sasaran. (4) Brosur, bertujuan untuk memberikan informasi secara langsung terhadap khalayak sasaran, isi yang di berikan diharapkan dapat memberikan pengetahuan terhadap khalayak sasaran. (5) X-banner, media yang digunakan pada saat program suntik roadshow dan diletakkan dibeberapa sekolah dan kampus. Tujuannya untuk memberikan informasi secara langsung kepada khalayak sasaran yang melihat media tersebut. (6) booth, media yang digunakan pada program suntik roadshow yang digunakan sebagai tempat pendaftaran dan pemberian merchandise. (7) Photobooth, media ini digunakan pada saat program suntik vaksin roadshow di car free day yang bertujuan sebagai sarana tempat foto. (8) Ambient media, media ini digunakan pada mobil ambulans yang merupakan mobil sarana program suntik vaksin roadshow. Dan (9) T-shirt, media ini digunakan sebagai identitas panitia dalam melakukan kampanye di program suntik vaksin roadshow. Sedangkan untuk media pendukungnya yaitu media sosial seperti facebook dan instagram. Untuk media merchandise-nya antara lain kipas tangan, stiker, tas pembalut, tumbler, goodie bag.

a. Poster
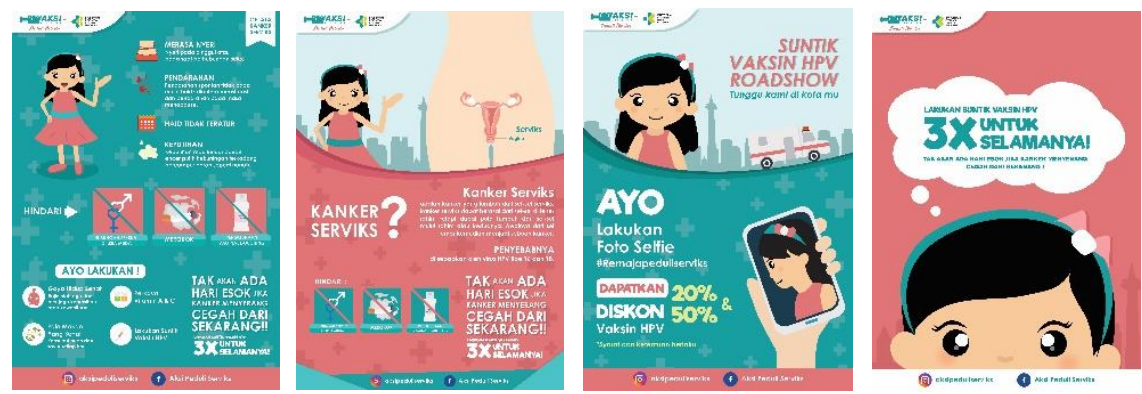

Gambar 3. Media Poster Kampanye Sumber: Denisha Octavia, $2017: 154-155$ 
b. Brosur

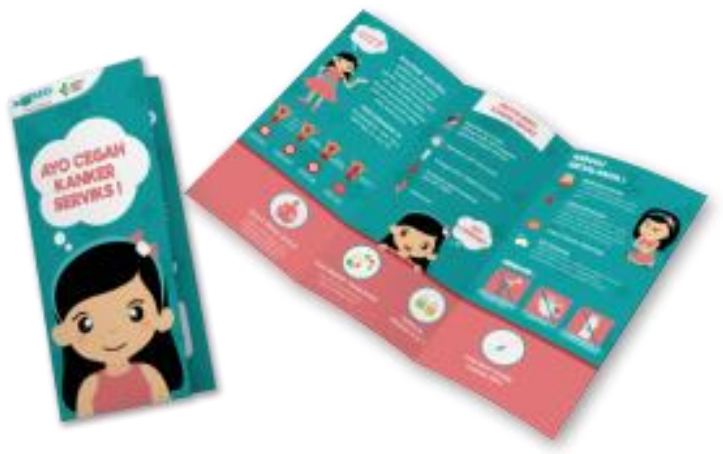

Gambar 4. Media Flyer Kampanye

Sumber : Denisha Octavia, 2017 : 157

c. X-Banner
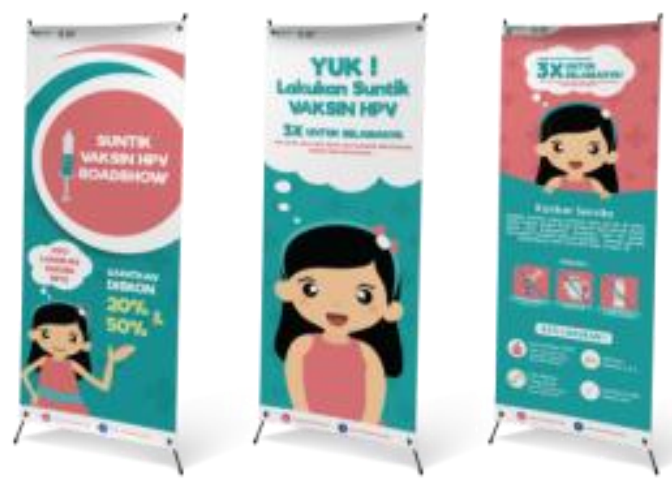

Gambar 5. Media X-banner Kampanye

Sumber : Denisha Octavia, $2017: 158$

\section{KESIMPULAN}

Minimnya pengetahuan remaja mengenai penyebab dan pencegahan kanker serviks melalui suntik vaksin HPV dikarenakan belum optimalnya media himbauan yang digunakan. Selain itu media tersebut masih kurang dapat menarik perhatian remaja. Perancangan kampanye sosial pencegahan kanker serviks terhadap remaja wanita di kota Jakarta ini bertujuan untuk memberikan awareness terhadap remaja melalui media komunikasi visual. Dengan mengikuti karakteristik 
remaja dalam melakukan pendekatan untuk menyampaikan informasi pentingnya menjaga pola dan gaya hidup sejak dini dalam mencegah penyakit kanker serviks dan melakukan suntik vaksin HPV agar pencegahan kanker serviks semakin efektif. Untuk mendapatkan hasil yang lebih baik untuk kedepannya perancangan kampanye sosial pencegahan kanker serviks ini sebaiknya dilakukan secara tersusun dan berkelanjutan dan perlunya memperluas kerja sama dengan pihakpihak yang berpotensi dalam menanggulangi pencegahan kanker serviks ini.

\section{PERNYATAAN PENGHARGAAN}

Penulis ingin mengucapkan besar terimakasih kepada dr. Niken Wastu Palupi, M.KM selaku kepala Subdirektorat Pengendalian Kanker Kementerian Kesehatan Republik Indonesia; Dr. dr. Yuditiya Purwosunu., Sp.OG-KFM, Ph.D selaku dokter spesialis kandungan beresiko tinggi; Dr. Antar Venus, M.A, Comm. selaku ahli kampanye dan seluruh responden yang telah berpartisipasi.

\section{DAFTAR PUSTAKA}

Octavia, Denisha., 2017. Perancangan Kampanye Sosial Pencegahan Kanker Serviks Terhadap Remaja Wanita di Kota Jakarta. Laporan Tugas Akhir. Openlibrary Telkom University

Palupi, Oktalisa Wardhani., 2016. Perancangan Animasi Motion Graphic Sebagai Media Informasi Wisata Edukasi di Kota Bandung. Laporan Tugas Akhir. Openlibrary Telkom University

Prasetyo, Herdi., 2016. Analisis AISAS (Attention, Interest, Search, Action, Share) pada Penggunaan ASUS Zenfone di Indonesia, Laporan Skripsi. Openlibrary Telkom University

Soewardikoen, Didit Widiatmoko., 2013. Metodologi Penelitian Visual Dari Seminar Ke Tugas akhir., CV Dinamika Komunika: Bandung.

Suryanto., 2015. Pengantar Ilmu Komunikasi. CV Pustaka Setia: Bandung. 
Winarto, Bagus Adi., 2015, Perancangan Kampanye Sosial Tujuh Zona Merah PKL Kota Bandung. Laporan Tugas Akhir. Openlibrary Telkom University Wiryanto., 2000. Teori Komunikasi Massa. Grasindo: Jakarta.

Tinarbuko, Sumbo., 2015. DEKAVE Desain Komunikasi Visual-Penanda Zaman Masyarakat Global. CAPS: Yogyakarta.

Venus, Antar., 2010. Manajemen Kampanye. Simbiosa Rekatama Media: Bandung.

\section{WEBSITE}

http://openlibrary.telkomuniversity.ac.id, 07-09-2017, 15:00 WIB

https://www.facebook.com/YPKSI, 07-09-2017, 17:35 WIB 